\title{
KASUS 'BAIQ NURIL' SEBAGAI REFLEKSI PEMBELAJARAN GUNA MENINGKATKAN MUTU ETIKA PROFESI KEPENDIDIKAN
}

\author{
Oleh \\ I Dewa Gede Darma Permana \\ Universitas Hindu Negeri I Gusti Bagus Sugriwa Denpasar \\ dewadarma75@gmail.com
}

diterima 30 Desember 2020, direvisi 21 Januari 2021, diterbitkan 28 Pebruari 2021

\begin{abstract}
The 'Baiq Nuril' case is a case involving a former honorary teacher at SMAN 7 Mataram, West Nusa Tenggara (NTB), named Baiq Nuril Maknun with his superior, Mr. Muslim, who is the principal of SMAN 7 Mataram. In this regard, this study is interested in examining the case to find out the reflection of its learning in order to improve the quality of educational professional ethics. In this study, several problems were also formulated, namely related to the complete chronology of the 'Baiq Nuril' case, regarding the ethics of the educational profession related to the 'Baiq Nuril' case, along with the reflection of learning from the case as an increase in the quality of educational professional ethics. This study uses a case study research type, with data collection methods using library research techniques and using data analysis from Miles and Huberman. The results of this study indicate that there are several educational professional ethics that were violated in the 'Baiq Nuril' case, especially those concerning the personal competence of education personnel. Through this research, it is hoped that it can provide a reflection of learning so that similar cases do not happen again in the future, and are useful in improving the ethics of the educational profession
\end{abstract}

\section{Keywords: Baiq Nuril, Reflection, Educational Professional Ethics.}

\section{PENDAHULUAN}

Peran pendidikan dalam suatu bangsa sangatlah besar dan vital. Pendidikan merupakan kunci masa depan suatu bangsa kedepannya. Keberhasilan atau kegagalan pembangunan suatu bangsa sangat ditentukan oleh keberhasilan pendidikannya. Pendidikanlah yang menjadi faktor utama dalam pembangunan suatu bangsa, sehingga memajukan mutu pendidikan adalah hal yang sangat perlu dilakukan pertama kali, sebelum nantinya benar-benar mempersiapkan pembangunan bangsa. Pendapat ini selaras dengan pandangan oleh beberapa ahli pendidikan seperti Don Adam dalam bukunya Education in National Development (1971), 
serta Arnold Anderson dan Mary J Bowman dalam bukunya Education and Economic Development (1965) (Nahdi, 2018: 121) yang memandang keberhasilan pembangunan suatu bangsa sangat ditentukan oleh keberhasilan pendidikan, karena pendidikan dipandang sebagai faktor utama dalam pembangunan suatu bangsa.

Dalam memajukan suatu pendidikan, ada beberapa faktor pendidikan yang perlu diperhatikan agar proses pendidikan berlangsung dengan baik, sehingga tujuan dari pendidikan tersebut dapat tercapai. Beberapa faktor pendidikan tersebut antara lain Faktor Tujuan, Faktor Pendidik, Faktor Peserta didik, Faktor Isi atau Materi, Faktor Metode Pendidikan, dan terakhir ada Faktor Situasi Lingkungan. Semua faktor pendidikan tersebut penting dan diperlukan dalam proses pembelajaran, serta saling mempengaruhi antara satu dan lainnya. Walaupun demikian, kemampuan dan kualitas Faktor Pendidik masih menjadi faktor dominan dalam pelaksanaan pendidikan (Marbun, 2018 : 93). Untuk itulah memperhatikan mutu Tenaga Kependidikan sebagai salah satu Faktor Pendidik sangat perlu dilakukan. Tenaga Kependidikan disini harus menjadi tauladan, orang yang digugu dan ditiru, agar peserta didik menerima pengetahuan yang dapat mengembangkan potensinya baik dari segi kecerdasan (kognitif), sikap atau karakter (afektif), maupun ketrampilan (Psikomotorik).

Memandang berbagai fenomena mengenai tenaga kependidikan di Indonesia, beberapa kalangan masyarakat Indonesia seakan terus-menerus mempertanyakan kualitas atau mutu tenaga kependidikan di Indonesia. Hal ini disebabkan karena banyaknya kasus yang bertentangan dengan nilai moral dan etika dalam dunia pendidikan yang melibatkan dan dilakukan oleh tenaga kependidikan itu sendiri. Hal ini seakan menjadi refleksi yang kurang baik bagi mutu pendidik di Indonesia.

Salah satu kasus tentang tenaga kependidikan yang cukup menarik perhatian publik adalah melibatkan seorang mantan guru honorer di SMAN 7 Mataram, Nusa
Tenggara Barat (NTB), Baiq Nuril Maknun, yang dinyatakan bersalah menyebarkan rekaman bermuatan anti kesusilaan dan dihukum enam bulan penjara serta denda $\mathrm{Rp}$. 500 juta dalam putusan kasasi Mahkamah Agung (MA) pada Tahun 2018 yang lalu (CNN Indonesia, 2019). Padahal dirinya sebenarnya diduga korban dari pelecehan seksual secara verbal yang dilakukan atasanya yaitu Pak Muslim yang berstatus sebagai Kepala Sekolah SMAN 7 Mataram saat itu. Pelecehan itupun direkam oleh Baiq Nuril dan tak sengaja disebar oleh rekannya Iman Mudawin ke Dinas Pemuda dan Olahraga (DISPORA) Mataram, lewat rekaman tersebut Pak Muslim pun di mutasi dari jabatannya. Pak Muslim yang merasa tidak terima pun justru melaporkan balik saudara Baiq ke polisi atas dasar Pasal 27 Ayat (1) Undang-undang Informasi dan Transaksi Elektronik (ITE). Kasus ini pun terus berbuntut panjang, hingga berlanjut ke meja persidangan. Pada awalnya, Pengadilan Negeri Mataram memutuskan Baiq tidak bersalah, namun lewat banding hingga kasasi Jaksa Penuntut Umum ke Mahkamah Agung. Akhirnya pada tanggal 26 September 2018 lalu, Mahkamah Agung memutuskan guru honorer tersebut bersalah. Walaupun pada akhirnya Baiq Nuril bisa dibebaskan usai Presiden Joko Widodo mendatangani Keputusan Presiden yang berisi amnesti pembebasan dirinya dari hukuman (Kompas.com, 2019).

Kasus 'Baiq Nuril' memang terbilang sudah selesai, akan tetapi jaminan untuk kasus seperti ini tidak akan terulang lagi tidak bisa dipastikan. Kasus-kasus yang melibatkan tenaga kependidikan ini tentu saja berhubungan dan berkaitan dengan materi kode etik dalam profesi pendidikan sebagai pedoman guru atau pendidik dalam hal bertindak di dunia pendidikan. Dengan mencari kronologi lengkap kasus 'Baiq Nuril', kemudian diimbangi dengan bahan ajar Etika Profesi Pendidikan yang berkaitan dengan kasus 'Baiq Nuril', penulis, tertarik mengkaji lebih jauh mengenai kasus tersebut dengan judul 'Kasus 'Baiq Nuril' sebagai Refleksi Pembelajaran guna Meningkatkan 
Mutu Etika Profesi Kependidikan". Diharapkan hasil penelitian ini dapat bermanfaat sebagai refleksi para tenaga kependidikan guna meningkatkan mutu etika profesinya, serta yang lebih penting bisa menjadi pembelajaran agar kasus yang sama tidak terulang lagi untuk kesekian kalinya.

\section{METODE}

Penelitian ini menggunakan jenis penelitian deskriptif dengan pendekatan studi kasus yang dimana penelitian mengkaji kasus dari 'Baiq Nuril'. Penelitian studi kasus sendiri (dalam Wahyuningsih, 2013: 3), adalah penelitian yang dimana peneliti menggali suatu fenomena atau kasus tertentu yang terjadi dalam suatu waktu dan kegiatan (program, event, proses, institusi sosial, atau kelompok sosial), serta mengumpulkan data informasi secara terperinci dan mendalam dengan prosedur pengumpulan data dalam selang waktu tertentu. Data-data tersebut sendiri dalam penelitian ini dikumpulkan dengan metode pengumpulan studi kepustakaan atau literatur. Studi kepustakaan merupakan penelitian yang bertujuan untuk mencari dasar pijakan atau pondasi untuk memperoleh dan membangun landasan teori, kerangka berpikir dan menentukan dugaan sementara (Darmadi, 2011). Peneliti mengumpulkan, membaca dan menganalisis berbagai sumber yang berkaitan dengan kasus 'Baiq Nuril' dan Etika Profesi Kependidikan. Sumber yang dikumpulkan berupa buku, artikel, jurnal, dan sumber lainnya.

Setelah literature ini diperoleh, literature itupun dianalisis dengan teknik analisis data Interaktif Miles dan Huberman yang dalam menganalisis data kualitatif terdiri dari tiga prosedur kegiatan, yaitu mereduksi data atau memilah data-data yang telah dikumpulkan sesuai dengan topik bahasan, menyajikan data yang telah dipilah terutama yang membantu menjelaskan keterkaitan antara kasus 'Baiq Nuril' dan Etika Profesi Kependidikan, dan pada prosedur terakhir, di tariklah suatu kesimpulan atau memverifikasi data yang telah ditelaah sesuai dengan keterkaitan tersebut.

\section{HASIL DAN PEMBAHASAN}

\section{Kronologi Lengkap Kasus 'Baiq Nuril'}

Kasus 'Baiq Nuril' menurut beberapa media cetak dan elektronik seperti CNN Indonesia yang memberikan info lengkap mengenai kronologi lengkap kasus ini dengan judulKronologi Kasus Baiq Nuril, Bermula Dari Percakapan Teleponper tanggal 18 November 2018 mengungkapkan, kasus ini dimulai pada Tahun 2012 lalu, dimana pada saat itu Baiq Nuril Maknun nama lengkapnya, masih menjadi seorang Guru Honorer di SMAN 7 Mataram. Dia sering ditelepon atasannya yaitu Pak Muslim yang notabene Kepala Sekolah di Instansi tersebut. Perbincangan lewat telepon antara Pak Muslim dan Baiq Nuril lebih mengarah pada perbincangan curhat Pak Muslim terkait pengalaman seksualnya bersama dengan wanita yang bukan istrinya dan hanya sedikit waktu membicarakan mengenai pekerjaan di sekolah tersebut. Berawal dari kesan curhat, Pak Muslim malah sering menelepon Baiq, nada bicara Pak Muslim pun malah mengarah ke nada-nada pelecehan, bahkan saat lembur, Pak Muslim juga sering memanggil Baiq Nuril ke kantornya untuk mendiskusikan hal yang sama (CNN Indonesia, 2018). Akibat hal ini, Baiq Nuril pun mulai terganggu dan merasa dirinya telah dilecehkan secara verbal, terlebih lagi gara-gara hal ini, orang-orang disekitarnya malah menganggap dirinya memiliki hubungan yang gelap dengan Sang Kepala sekolah itu.

Tidak tahan dengan segala tekanan pikiran dan kata-kata Pak Muslim tersebut, tanpa melewatkan kesempatan, Baiq Nuril akhirnya mampu merekam perbincangannya dengan Pak Muslim yang berisi unsur pelecehan tersebut secara diam-diam, tepatnya sekitarbulan Agustus Tahun 2012, pada pukul setengah 5 sore. Rekaman ini, niat awal Baiq Nuril hanyalah dijadikannya bukti kuat bahwa dirinya tak memiliki hubungan gelap dengan atasannya itu, dan tidak ada niatan sama sekali untuk melaporkan perbincangan tersebut kepada pihak yang 
berwenang karena takut akan posisinya. Tetapi sialnya, dua tahun setelahnya pada Desember Tahun 2014, teman-teman kerjanya terutama Imam Mudawin, yang ia ajak berdiskusi soal hal ini malah melaporkan rekaman ini kepada pihak yang berwenang yaitu Dinas Pemuda dan Olahraga (DISPORA) Mataram. Dengan adanya laporan ini pun karir Baiq Nuril pun berakhir di SMAN 7 Mataram, dan disusul Pak Muslim selaku Kepala Sekolah yang dimutasi. Merasa tidak terima aibnya didengar oleh banyak orang, Pak Muslim pun marah besar meminta rekaman itu dihapus dan balik melaporkan Baiq Nuril ke polisi atas dasar Pasal 27 Ayat (1) Undang-undang Informasi dan Transaksi Elektronik (ITE).

Kemudian lanjut, menurut harian Kompas.com yang terbit tanggal 9 Juli 2019 dengan judul Perjalanan Panjang Baiq Nuril Mencari Keadilan, pelaporan ke pihak Polres Mataram dilakukan oleh Pak Muslim kepada Baiq Nuril pada tanggal 17 Maret 2015 atas dugaan pelanggaran UU ITE. Akibat pelaporan itu Baiq Nuril harus diperiksa di dan akhirnya resmi ditahan pada 27 Maret 2017. Hal ini pun memaksa suami Nuril pun berhenti bekerja pada salah satu rumah makan di Gili Trawangan, dan memilih mengurus ketiga anak kecilnya. Mirisnya, Baiq Nuril yang pada mulanya sebagai korban justru ditahan, sementara Pak Muslim yang diduga melakukan pelecehan seksual secara verbal justru beberapa bulan setelahnya naik pangkat menjadi kepala bidang di salah satu dinas di Pemerintahan Kota Mataram. Dengan kondisi anaknya yang masih kecil, dan alasan kemanusiaan, Baiq Nuril pun lewattim kuasa hukumnya mengajukan surat penangguhan penahanan agar dapat merawat anakanaknya.Untuk membantunya menjalani masa penangguhan beberapa pihak kurang lebih 28 nama membantuBaiq Nuril sebagai jaminan penangguhan penahanannya. Pihakpihak tersebut diantaranya ada, Kepala Dinas Perdagangan, Kepala Dinas Sosial,Kepala Dinas Pemberdayaan Perempuan dan Perlindungan Anak, Ketua Komisi V DPRD Provinsi NTB dan beberapa lembaga beserta pihak lainnya yang merasa ada tidak yang tidak adil terhadap kasus Baiq Nuril tersebut. Hasil sidang pertama Kasus 'Baiq Nuril' dalam persidangan di Pengadilan Negeri Mataram sebenarnya telah memvonis bebas Baiq Nuril karena tidak ada bukti jelas bahwa Nuril melanggar Pasal 27 Ayat 1 UU ITE. Namun kasus tidak selesai sampai disana, Jaksa penuntut umum mengajukan kasasi ke Mahkamah Agung Pada 26 September 2018. Dari sinilah keputusan yang kurang baik diterima Baiq Nuril, Mahkamah Agung malah memutus Nuril bersalah dan dijatuhi hukuman penjara 6 bulan serta denda Rp 500 juta, karena telah terbukti melakukan tindak tindakan pidana lewat bukti rekaman perbincangan perbuatan asusila Kepala Sekolahnya. Surat panggilan untuk Nuril akhirnya dikeluarkan pada tanggal 16 November 2018, dan berdasarkan surat tersebut, Nuril harus menghadap ke Jaksa Penuntut Umum pada tanggal 21 November 2018 (Kompas.com, 2019).

Keputusan Mahkamah Agung kepada Baiq Nuril memunculkan berbagai penolakan dari berbagai pihak baik itu masyarakat biasa, tokoh publik, aktivis sampai artis sekalipun. Dukungan kepada Nuril pun mulai berdatangan, petisi dalam jaringan pun yang dikeluarkan oleh Koalisi Masyarakat Sipil Save Ibu di laman change.org yang mendesak Presiden Joko Widodo agar memberikan amnesti kepada Baiq Nuril. Solidaritas dari Mataram tempat tinggal Nuril juga berdatangan. Ratusan simpatisan yang menamai dirinya 'Solidaritas untuk Nuril' pada hari Minggu, 18 November 2018 pun menggelar aksi tolak eksekusi terhadap Nuril, di Jalan Udayana Mataram. Sambil menangis, Nuril pun turut hadir di tengah aksi masa tersebut. Terakhir dukungan juga mengalir dari Institute for Criminal Justice Reform (ICJR).Isi Keputusan Kasasi yang memiliki nomor 574K/Pid.Sus/2018 menyatakan dengan jelas bahwa Baiq Nuril telah terbukti bersalah melakukan pelanggaran tindak pidana. Hal ini akhirnya menuai kritik kemudian menjadi bahan diskusi dari Institute for Criminal Justice Reform (ICJR). ICJR menyatakan bahwa hakim di dalam kasus 
'Baiq Nuril' semestinya berpedoman pada Peraturan Mahkamah Agung (Perma) Nomor 3 tahun 2017 yang berisi tentang Pedoman Mengadili Perempuan Berhadapan dengan Hukum. Pasal 3 huruf b sebagai bagian dari Perma tersebut telah jelas berisi hakim yang mengidentifikasi situasi suatu perlakuan, tidak setara yang diterima Baiq Nuril yang berhadapan dengan hukum. ICJR juga menyatakan dengan baha hal yang ada di dalam Pasal 27 ayat (1) Undang-Undang ITE, semestinya digunakan untuk penyebaran dalam sistem elektronik tanpa harus dikaitkan dengan pasal kesusilaan dalam KUHP. Pasal tersebut harus jelas menyatakan bahwa perbuatan yang dilarang adalah penyebaran konten bermuatan pelanggaran asusila yang 'diniatkan' untuk disebarkan kepada publik, bukan tindakan yang tidak diniatkan, apalagi tidak disengaja seperti yang dilakukan Baiq Nuril (Kompas.com, 2019).

Untuk mencari keadilan atas putusan hukum yang mengikatnya, Baiq Nuril pun balik melaporkan mantan atasannya Pak Muslim ke polisi. Menurut berita dari CNN Indonesia yang terbit tanggal 20 November 2018 dengan headline Baiq Nuril Laporkan Eks Atasannya: Saya Mencari Keadilan mengungkapkan pada bagian awalnya, Baiq Nuril melaporkan atasannya ke Polda Nusa Tenggara Barat (NTB), Senin (19/11) lalu terkait dugaan pelecehan seksual verbal yang dia alami, sesuai dengan yang ada dalam Pasal 294 ayat 2 butir 1 KUHP.

Laporan terhadap Pak Muslim mantan Kepala Sekolah SMAN 7 Mataram daripihak Baiq Nuril teregistrasi memiliki nomor: LP/334/XI/2018/NTB/SPKT, pada tanggal 19 November 2018. Laporan ini juga sebagai sarana penuntut keadilan terhadap apa yang telah diterimanya dan mengajak seluruh perempuan agar tidak takut melaporkan kepada pihak yang berwajib jika menerima perlakuan yang sama, agar tidak ada lagi kasus yang sama dikemudian hari (CNN Indonesia, 2018). Walaupun telah melengkapi berkas pelaporan disertai dengan menghadirkan sejumlah ahli untuk memperkuat laporannya, seperti ahli bahasa, ahli hukum, serta pihak Komnas Perempuan.
Keluarga Baiq Nuril harus menanggung kecewa karena pihak kepolisian menghentikan pemeriksaan laporan Baiq Nuril Maknun terhadap eks Kepsek SMAN 7 Mataram tersebut. Hal ini dikarenakan laporan pihak kuasa hukum Baiq Nurik dianggap tak memiliki cukup bukti dan tidak mampu menghadirkan saksi yang memadai (detik.com, 2018). Laporan Baiq Nuril Maknun atas tindakan dugaan pelecehan seksual secara verbal oleh mantan atasannya atau mantan kepala SMA 7 Mataram, Muslim ke Polda Nusa Tenggara Barat (NTB) akhirnya resmi dihentikan pada tanggal 28 Januari 2019.Pihak Kepolisian Polda Nusa Tenggara Barat (NTB) berdalih merasa kesulitan mencari unsur perbuatan cabul seperti yang dilaporkan Nuril dan kuasa hukumnya, pelapor juga tak memiliki saksi yang kuat dalam pelaporannya.

Tidak menyerah sampai disana, perjuangan pihak Baiq Nuril pun diarahkan dengan mengajukan peninjauan kembali pada tanggal 3 Januari 2019 kepada Mahkamah Agung (MA) atas keputusan MA yang telah membuat Baiq Nuril bersalah. Namun Pihak Baiq Nuril harus menanggung rasa kecewa untuk kedua kalinya, setelah tanggal 4 Juli 2019, Mahkamah Agung (MA) menolak ajuan Peninjauan Kembali tersebut. MA menilai, karena Nuril sudah dapat merekam percakapan mesum Kepala SMAN 7 Mataram, Haji Muslim, yang membuat keluarga besar Haji Muslim malu, Baiq pantas menerima ganjaran hukuman kurungan dan denda(Kompas.com, 2019). Lebih lanjut dalam artikel nasional yang diterbitkan oleh media Kompas.com dengan judul Ini Alasan MA Tolak PK Sehingga Baiq Nuril Tetap Terancam Penjara 6 Bulanpada tanggal 5 Juli 2019, majelis hakim sebagai petugas di sidang Kasus Baiq Nuril, yang diketuai oleh Suhadi mengatakan,hukuman dalam vonis yang diberikan kepada Baiq Nuril tersebut sudah tepat dan sesuai dengan pelanggaran Pasal 27 Ayat 1 dan Pasal 45 ayat 1 UndangUndangnomor 11 Tahun 2008 tentang ITE, dan hasil rekaman itu disimpan oleh terdakwa. Kemudian lebih lanjut, barang bukti berupa hasil rekaman yang tersimpan 
lalu diserahkan kepada saudara Imam Mudawin, lalu tanpa terduga saksi Imam Mudawi sebagai rekan Baiq Nuril memindahkan ke laptopnya, dan akhirnya tanpa baiq Nuril dugadisebarkan begitu saja, ungkapnya. Hal ini berarti terdakwa pihak Baiq Nurilah yang telah menyerahkan ponsel miliknya kepada orang lain, sehingga dapat didistribusikan dan diakses yang memuat konten pembicaraan bermuatan tindak kesusilaan, hal ini tidak dapat dibenarkan. Maka dari itu, lanjutnya, atas alasan tersebut permohonan PK kuasa hukum Baiq Nuril ditolak (Ristianto, 2019). Setelah mengalami dua penolakan, harapan satu-satunya bagi Baiq Nuril agar bebas hanya lewat pemberian amnesti dari pihak Presiden Joko Widodo.

Senin, 15 Juli 2019, pihak Baiq Nuril akhirnya menyambangi Kantor Staf Presiden (KSP), Jakarta, dengan tujuan menyerahkan surat permohonan Amnesti kepada Presiden Joko Widodo (Jokowi).

Dalam hal ini Baiq Nuril didampingi oleh tim kuasa hukumnya dan anggota Dewan Perwakilan Rakyat (DPR) Rieke Diah Pitaloka. Akhirnya pengajuan amnesti pun terkabul. Penekenan oleh Presiden Jokowi terhadap Keputusan Presiden amnesti menjadi ujung cerita kasus 'Baiq Nuril'. Lewat amnesti yang diatur dalam UndangUndang Darurat Nomor 11 Tahun 1954, semua akibat hukum pidana pun dihapuskan. Presiden Joko Widodo pun memastikan Keppres Amnesti untuk Baiq Nuril sudah benar-benar diteken, dan Baiq Nuril sudah bisa dinyatakan bebas. Dengan Amnesti ini, kasus Baiq Nuril pun berakhir dengan baik (detik.com, 2019).

\section{Etika Profesi Kependidikan yang Berkaitan dengan Kasus 'Baiq Nuril'}

Membahas tentang etika, etika berhubungan dengan cara pandang individu maupun kelompok dalam memandang dan memberikan penilaian terhadap suatu perilaku, apakah perilaku tersebut dalam kategori salah atau benar, buruk atau baik. Hal ini sesuai dengan pandangan F. MagnisSuseno, yang menyatakan bahwa etika adalah sesuatu ajaran atau teoritis yang terimplementasikan lewat moral tentang usaha manusia untuk memakai akal budi dan daya pikirnya untuk memecahkan masalah bagaimana dia harus hidup, dan dari sana mau menjadi pribadi yang baik (Haris, 2010: 35). Sementara profesi diartikan sebagai pekerjaan yang dalam melaksanakan tugasnya memerlukan atau menuntut suatu keahlian khusus, menggunakan teknik-teknik ilmiah, serta pengabdian atau dedikasi yang tinggi. Kemampuan atau keahlian ini didapatkan dari lembaga pendidikan yang memang khusus untuk membentuk dan memberikan hal tersebut, sehingga dalam hal ini dilengkapi dengan kurikulum yang dapat dipertanggungjawabkan Rusman (2011:16). Dari pengertian tersebut, dapat diketahui bahwa, kata profesi senantiasa merujuk pada suatu pekerjaan atau kewajiban yang menuntut keahlian, tanggung jawab, dan pengabdian yang penuh dedikasi terhadap bidang tugas yang telah ditetapkannya. Sehingga dalam ini pula, tidak sembarang orang bisa menyandang gelar profesi.

Jadi, dari dua pengertian tersebut, etika profesi merupakan suatu ajaran yang memberitahukan tentang baik atau buruknya suatu pikiran, sikap, perbuatan, serta kewajiban yang diterima oleh masyarakat umum tentang sebuah profesi yang ada. Gunawan (2019: 8 dalam Perdani dkk, 2019: 3) mengemukakan bahwa standar kategori dalam etika adalah cinta kepada sesama manusia, tidak egois, dan tidak apatis yang hanya cinta pada diri sendiri. Sehingga dalam hal ini, Etika profesi adalah salah satu standar moral agar dikatakan profesional yaitu dapat mengambil keputusan yang tidak subjektif terhadap sebuah masalah, penuh dengan tanggung jawab dan memiliki keahlian serta kemampuan.

Etika profesi dikatakan efektif jika dilandasi oleh nilai dan cita-cita yang ada dilingkungan profesi dan merupakan penerapan standar moral individu yang menjalani profesi tersebut. Etika profesi sekaligus menjadi tolak ukur perilaku anggota profesi dan upaya pencegahan perilaku tidak etis yang dilakukan oleh anggota profesi. Dalam etika profesi ini, dikenal juga adanya 
yang namanya kode etik profesi. Kode etik profesi sendiri diartikan sebagai aturan yang ditulis atau sistem norma yang secara tegas, jelas, dan terperinci tentang norma-norma yang perlu diperhatikan oleh individu di dalam sebuah profesi untuk melaksanakan tugas profesinya sesuai dengan yang dimandatkan dan berdasar aturan dalam kehidupan bermasyarakat. Kode etik profesi dibuat oleh organisasi profesi, yang bertujuan untuk mengangkat citra positif profesi, meningkatkan kesejahteraan para anggota profesi, mengembangkan dan meningkatkan mutu pengabdian anggota profesi, serta mengembangkan dan meningkatkan mutu keorganisasian pada suatu profesi (Perdani dkk, 2019: 5-6).

Kasus 'Baiq Nuril' berlangsung dalam lingkup dunia pendidikan, terutama mengenai profesi kependidikan. Sehingga dalam menelaah kasus ini, perlu kaca mata guru beserta kode etik keguruan untuk memandangnya. Guru menurut Suhardana (2010 dalam Astawa, 2018: 97) merupakan seseorang yang patut dimuliakan atau pembimbing spiritual. Namun sebelum dihormati dan dimuliakan, guru harus mampu menerapkan kode etik profesinya.

Kode etik profesi guru sendiri merupakan kumpulan nilai serta norma profesi yang disusun dengan baik dan sistematis dalam sebuah sistem (Perdani dkk, 2019: 6). Kode etik profesi guru dapat berfungsi sebagai landasan moral dan pedoman tingkah laku guru dalam menjalankan tugas sebagai guru baik dalam sekolah maupun dalam kehidupan bermasyarakat, sebagai sarana kontrol sosial bagi masyarakat yang berprofesi sebagai guru, serta mencegah campur tangan pihak diluar dalam organisasi profesi guru tentang hubungan etika dalam keanggotaan profesi, sanksi pelanggaran kode etik profesi guru bisa berupa sanksi moral atau teguran dan sanksi yang lebih keras yaitu dikeluarkan dari organisasi (Karuru dan Tangkeallo, 2017: 22).

Kode etik guru dalam dunia pendidikan sangat penting sebagai sarana pembentuk sikap professional seorang guru yang menyandang profesionalisme. Hal ini dikarenakan guru akan dapat mengatur hubungannya dengan baik bersama kepala sekolah, bersama sesama guru, bersama anak didiknya, bersama lingkungannya seperti orang tua siswa jika mempunyai etika yang mulia dan baik pula (Wandi dan Nurhafizah, 2019: 34). Jadi dapat diketahui bahwa kode etik guru yang mampu dijunjung tinggi oleh seorang pendidik secara tidak langsung guru tersebut akan memiliki nilai-nilai profesionalisme sehingga kedepannya mampu menanamkan perilaku dan karakter yang baik kepada peserta didik.

Lebih lanjut, etika seorang guru juga menyatakan bahwa pekerjaan seorang guru tidak hanya mentransfer ilmunya kepada anak didik, namun berkaitan juga dalam kegiatan merubah perilaku yang berkaitan dengan moral, norma dan penghormatan, sehingga guru dalam hal ini juga dituntut untuk memiliki kemampuan dasar, yang diperlukan sebagai pendidik, pembimbing, dan pengajar (Sutarsih, 2013). Untuk itu, memandang dan menemukan solusi terkait kasus pelecehan yang melibatkan guru, salah satunya kasus 'Baiq Nuril' dalam hal ini, sangat diperlukan kode etik guru sebagai pedoman sekaligus pelindung guru itu sendiri. Kode etik guru dalam hal ini dibentuk berdasarkan prinsipprinsip yang sama dengan kode etik jabatan yang lain, yaitu tanda-tandanya atau simbol yang berupa kata-kata tulisan atau benda yang disepakati untuk maksud tertentu, misalnya untuk menjamin suatu berita, keputusan atau suatu kesepakatan suatu organisasi.

Kode etik juga dapat berarti kumpulan peraturan yang sistematis karena disusun secara teratur dalam norma atau asas yang diterima oleh suatu kelompok tertentu sebagai landasan tingkah laku sehari-hari di masyarakat maupun di tempat kerja. Dalam kode etik profesi inilah memiliki tugas sebagai nilai yang dijadikan pedoman dalam bersikap, bertingkah laku dan berbuat oleh tenaga pendidik dalam melaksanakan tugas dan kewajibannya di kehidupan sehari-hari sesuai jabatan yang diampunya. Indonesia juga memiliki kode etik guru, yang khusus dipergunakan oleh guru Indonesia dalam melaksanakan tugasnya. 
Kode etik guru ini berhasil dirumuskan sebagai hasil kongres Persatuan Guru Republik Indonesia (PGRI) ke XIII pada tanggal 21-25 November 1973 di Jakarta. Isi rumusan Kode Etik Guru Indonesia tersebut (Karuru dan Tangkeallo, 2017: 21-23) kurang lebih berbunyi sebagai berikut:

1) Guru berbakti serta memberikan bimbingan kepada peserta didik untuk dibentuk menjadi manusia berjiwa Pancasila.

2) Guru berlaku jujur secara profesional.

3) Guru senantiasa berupaya untukmengetahui seluk-beluk peserta didik sebagai bahan dasar dalam melakukan bimbingan meupun pembinaan.

4) Guru menciptakan suasana belajar di sekolah yang ia ampu dengan sebaikbaiknya serta berusaha menunjang keberhasilan PBM(proses belajar mengajar).

5) Guru memiliki hubungan baik baik dengan orang tua murid, dan masyarakat sekitarnya untuk melakukan pembinaan serta bertanggung jawab bersama-sama.

6) Guru secara pribadi maupun bersamasama dengan segala pihak mengembangkan dan meningkatkan martabat dan mutu profesi keguruan.

7) Guru memelihara hubungan antar sesama profesi keguruan dengan bekal semangat kekeluargaan dan kesetiakawanan dalam lingkup nasional.

8) Guru bersama-sama menjaga dan meningkatkan mutu organisasi Persatuan Guru Republik Indonesiasebagai suatu kewajiban, perjuangan, dan pengabdian yang mesti dilakukan.

9) Guru berupaya menjalankan kebijakan pemerintah yang telah diberikan kepadanya dalam bidang pendidikan maupun pembangunan pendidikan Indonesia.

Kode etik tersebutlah yang digunakan sebagai pedoman tenaga pendidik terutama guru dalam menjalankan profesinya. Kode etik tersebut juga menjadi cermin 4 kompetensi yang harus dimiliki seorang guru antar lain:

1) Kompetensi profesional yang identik dengan kode etik guru point 2,6,7,8.

2) Kedua, kompetensi pedagogik yang identik dengan kode etik guru point $1,3,4$.

3) Ketiga kompetensi personal identik dengan kode etik guru point 3,5,7,9.

4) Kemudian terakhir kompetensi sosial yang identik dengan kode etik guru point $5,6,7$.

Kode etik guru Indonesia juga secara tegas menyatakan guru adalah insan yang layak ditiru dan digugu khususnya oleh peserta didik, yang dalam melaksanakan tugas berpegang teguh pada prinsip Ing Ngarso Sung Tulodo (di depan memberikan panutan), Ing Madyo Mangun Karso (di tengah memberikan semangat), serta Tut Wuri Handayani (di belakang memberikan dorongan) yang dipergunakan dalam usaha mewujudkan prinsip-prinsip tersebut guru Indonesia ketika menjalankan tugas-tugas profesional sesuai dengan perkembangan ilmu dan teknologi.

Lebih lanjut, secara lebih khusus, kasus 'Baiq Nuril' juga melibatkan Kepala Sekolah terutama dari segi kepribadiannya. Sehingga dalam hal ini, penting dan juga perlu mengetahui seluk-beluk kompetensi kepribadian Kepala Sekolah. Kepala Sekolah sendiri, dapat diartikan sebagai pemimpin sekolah atau lembaga tempat menerima dan memberi pelajaran (Basri, 2014: 40 dalam Ananda, 2018: 72).

Kepala sekolah adalah guru yang mempunyai kemampuan dan kemauan untuk menjadi pemimpin dan mengarahkan setiap segala sumber daya yang ada pada suatu sekolah baik guru, pegawai, maupun siswa, sehingga segala sumber daya tersebut dapat didayagunakan secara optimaldalam mencapai tujuan bersama yang sudah disepakati. Sehingga dalam hal ini, Kepala Sekolah (dalam Nurmawati dan Mandra, 2018: 185) adalah sebuah aspek atau 
komponen yang penting dalam ranah pengelolaan dan penyelenggaraan pendidikan untuk penjaminan mutu pendidikan melalui pengawasan dalam bidang perencanaan, pelaksanaan, dan juga evaluasi dalam pendidikan di sekolah. Jadi lahirnya generasi penerus bangsa yang mampu dan berkompeten sangat ditentukan oleh mutu pendidikan yang baik dan berkualitas. Kemudian dalam menjalankan tugasnya, perlu didasarkan pada hakikat etika profesi pendidikan yang sudah dijelaskan sebelumnya dan menjalankan kompetensi yang menjadi dasar dari profesinya.

Berbicara mengenai beberapa hal tentang Kepala Sekolah, yang memiliki kaitan dengan etika profesi pendidikan. Dalam etika profesi pendidikan, Kepala Sekolah juga memiliki syarat-syarat kompetensi, sama halnya dengan seorang guru. Hal ini dikarenakan seperti pandangan Danim (2009: 13), Kepala sekolah dalam menjalankan tugasnya, tidak hanya bertugas mengelola sekolah secara stagnan atau statis, melainkan dalam hal ini, mesti bisa sebagai pemicu dan penggerak segala potensi yang berhubungan langsung atau tidak langsung bagi kepentingan proses pembelajaran siswa. Jika dalam hal ini kepala sekolah gagal menciptakan kondisi pembelajaran yang efektif dan efisien, secara langsung atau tidak langsung akan berdampak pada mutu etika profesi kependidikan dan prestasi peserta didik di masa yang akan datang. Hal ini dikarenakan Kepala Sekolah adalah pemimpin sekolah, sehingga menjadi panutan bagi segala aspek di sekolah agar diberikan bimbingan dan pembinaan dengan harapan dan upaya mewujudkan proses pembelajaran yang efektif.

Kemudian mengenai Kepala Sekolah juga secara yuridis, terdapat Peraturan Menteri Pendidikan Nasional Republik Indonesia Nomor 13 tahun 2007 tentang Standar Kepala Sekolah/ Madrasah (Ananda, 2018: 75), ditentukan beberapa kompetensi yang harus melekat pada diri seorang kepala sekolah. Dari beberapa kompetensi tersebut, kompetensi kepribadian merupakan kompetensi yang perlu dibahas secara lebih khusus, karena dalam hal ini erat kaitannya dengan kasus 'Baiq Nuril'.

Kompetensi kepribadian sendiri merupakan kemampuan kepala sekolah yang berkaitan dengan karakter kepala sekolah itu sendiri. Kemampuan ini (dalam Ananda, 2018: 75-76) dipaparkan sebagai berikut:

1) Pertama, Kepala sekolah mesti memiliki akhlak yang mulia, sehingga bisa menjadi teladan bagi komunitas di sekolah atau madrasah.

2) Kedua, Kepala Sekolah sudah sepantasnya berintegritas dan memiliki kepribadian yang mencerminkan seorang pemimpin. Hal ini dapat ditunjukkan dengan konsisten dan berkomitmen dalam berpikir, bersikap, berucap, dan berbuat untuk tugas pokok dan fungsi yang telah ia dapatkan, serta memiliki keinginan yang kuat dalam pengembangan diri sebagai Kepala Sekolah.

3) Ketiga, Kepala Sekolah mampu bersikap terbuka dalam melaksanakan tugas pokok dan fungsi, seperti terbuka atas saran dan kritik yang disampaikan oleh atas, teman sejawat, bawahan, dan pihak lain atas pelaksanaan suatu tugas pokok dan fungsi.

4) Keempat, Kepala Sekolah juga mampu mengendalikan diri dalam menghadapi masalah dalam pekerjaan sebagai Kepala Sekolah dengan selalu bersikap teliti, cermat, hati-hati dan tidak tergesagesa dalam melaksanakan suatu tugas pokok dan fungsi.

5) Kemudian yang terakhir, orang yang menjabat sebagai Kepala Sekolah karena memang memiliki bakat dan minat untuk menduduki jabatan sebagai pemimpin pendidikan, sehingga dalam hal ini harus berusaha menjadi pemimpin yang tidak mudah putus asa dan senatiasa semangat menjalankan tugasnya. 


\section{Pembelajaran dari Kasus 'Baiq Nuril' sebagai Peningkatan Mutu Etika Profesi Kependidikan}

Dari kronologis kasus, kemudian disambung dengan pembahasan etika profesi pendidikan yang berkaitan dengan kasus 'Baiq Nuril'. Dapat diketahui bahwa ada beberapa nilai dan kode etik profesi kependidikan yang yang dilanggar dalam kasus tersebut. Untuk itulah dalam pembahasan ini, permasalahan tersebut akan dibahas lebih dalam lagi. Yang pertama tentang kode etik profesi secara umum. Kode etik profesi yang sudah jelas berperan sebagai sistem norma yang mengatur individu dalam sebuah profesi, agar individu tersebut dapat melaksanakan tugasnya dengan baik dan semestinya. Dalam kasus 'Baiq Nuril', tujuan kode etik profesi seperti mengangkat citra positif, mutu, dan kesejahteraan profesi beserta organisasi profesinya sudah dilanggar dalam kasus ini. Kasus ini seakan sudah merusak citra positif dan mutu profesi, terutama profesi keguruan secara khususnya.

Kedua tentang kode etik profesi guru. Kode etik guru yang pada umumnya berfungsi sebagai landasan moral dan tingkah laku guru dalam melaksanakan tugasnya sebagaimana mestinya serta membentuk sikap profesional individu dalam profesi keguruan juga sudah diacuhkan dalam kasus ini. Dapat dilihat bahwa dari kasus ini, nilai moral yang baik tidak diimplementasikan dan dicontohkan oleh tenaga kependidikan terkait. Bisa di ambil contoh, perbuatan yang dilakukan oleh Pak Muslim, Kepala Sekolah SMAN 7 Mataram dengan mengucapkan atau melakukan pelecehan seksual secara verbal kepada salah satu anggotanya yaitu Baiq Nuril merupakan contoh yang kurang baik untuk dihormati dan ditiru oleh orang lain, terutama kepada para peserta didik yang bersekolah di SMAN 7 Mataram.

Undang-Undang No. 14 Tahun 2005 tentang Guru dan Dosen dan Peraturan Menteri Pendidikan Nasional Republik Indonesia Nomor 13 tahun 2007 tentang Standar Kepala Sekolah/Madrasah, sudah jelas menyatakan bahwa kompetensikompetensi yang harus dimiliki oleh guru professional termasuk Kepala Sekolah salah satunya adalah kompetensi kepribadian. Kompetensi kepribadian merupakan kompetensi yang berhubungan dengan kepribadian seorang pendidik yang bermoralitas dan berakhlak mulia, serta menjadi tauladan dan panutan bagi anak-anak didik yang diajarnya. Hal ini dapat dipertegas lagi dalam Peraturan Menteri Pendidikan dan Kebudayaan Nomor 16 tahun 2017, kompetensi kepribadian meliputi lima komponen pokok, antara lain:

1) Pertama, bertindak sesuai norma agama, hukum, sosial dan kebudayaan nasional Indonesia.

2) Kedua, menampilkan diri sebagai pribadi yang jujur, berakhlak mulia, dan teladan bagi peserta didik dan masyarakat.

3) Ketiga, tampil sebagai pribadi yang seimbang, dewasa, arif, dan berwibawa dalam setiap tindakan kepada keluarganya baik di rumah maupun di sekolah.

4) Keempat, menunjukkan etos kerja, tanggung jawab yang tinggi, rasa bangga menjadi guru, dan rasa percaya diri.

5) Kemudian yang terakhir atau kelima, menjunjung tinggi kode etik profesi guru.

Perilaku Pak Muslim terhadap Baiq Nuril sudah mencerminkan hilangnya teladan dan pedoman moral yang dimiliki oleh seorang guru. Percakapan sebagai sarana untuk melakukan pelecehan seksual secara verbal adalah bukti bahwa teladan moral sebagai implementasi kompetensi kepribadian telah dinodai. Apalagi dirinya disini yang sudah berprofesi sebagai kepala satuan pendidikan, semestinya bisa menjadi panutan bagi anggota-anggotanya dengan berperilaku yang lebih baik.

Pelanggaran-pelanggaran moral dalam kasus 'Baiq Nuril' harus bisa dijadikan refleksi pembelajaran oleh para tenaga kependidikan sehingga kedepannya bisa dicegah dan diantisipasi agar tidak terjadi lagi kasus yang mirip untuk kesekian kalinya. Dari 
segi profesi keguruan dan kode etik keguruan, pengawasan dan pelatihan terhadap guru mesti ditingkatkan terutama dari segi karakter, yang selama ini terlalu fokus dalam kompetensi profesional dan pedagogik. Sehingga dalam hal ini, guru akan senantiasa berusaha menaati kode etik keguruan yang sudah ditetapkan oleh organisasi profesi keguruan sebagai bentuk penerapan etika dalam kehidupan bermasyarakat. Dengan latihan dan pembelajaran karakter tersebut, guru harus digembleng untuk memiliki etika yang baik dalam menghadapi sebuah masalah serta mahir dalam membuat keputusan yang objektif, tidak hanya pandai dalam ilmu secara kognetif saja.

Guru dalam hal ini adalah contoh bagi siswanya. Apa yang dilakukan oleh guru bisa saja menjadi repleksi untuk dicontoh oleh siswanya baik itu hal yang bermoral maupun yang melanggar etika. Jadi etika profesi guru harus diterapkan pada kehidupan guru dikelas maupun dimasyarakat. Guru yang dikatakan baik yaitu guru yang professional dan menjunjung tinggi etika profesi guru. Guru profesional harus mempunyai kecakapan baik dalam bidang akademik maupun sosial yang mumpuni. Disamping juga, pendidik baik kepala sekolah maupun guru, harus mempunyai jiwa yang tulus tanpa pamrih dalam melaksanakan tugas-tugasnya yang mulia kepada anak didiknya.

Guru harus mendahulukan kepentingan bersama, mengabdi untuk masyarakar di atas kepentingan pribadinya. Dari sini menaati kode etik keguruan yang sudah ditetapkan oleh organisasi profesi keguruan yaitu PGRI, adalah suatu kewajiban dan sebagai bentuk penerapan ilmu etika dan moral dalam kehidupan baik di sekolah, di rumah, maupun di masayarakat. Guru sebagai orang yang digugu dan ditiru dalam hal ini dapat menilai suatu perilaku, apakah perbuatan tersebut baik atau tidak sesuai dengan norma serta moral yang berlaku dalam masyarakat. Dari sana, ketika sesuatu diarahkan ke hal yang baik, akan tercipta suatu hubungan yang baik antara guru, murid, dan masyarakat sekitar. Demi terwujudnya hal ini, perlu juga peran seluruh komponen pendidikan seperti pemerintah, warga sekolah, masyarakat, dan lain-lain agar bersedia saling bahu-membahu mengawasi dan memperbaiki etika profesi keguruan, sehingga kasus yang sama tidak terulang lagi serta mutu etika profesi kependidikan bisa ditingkatkan.

Selain penguatan karakter dan implementasi etika keguruan lewat pelatihan. Melalui refleksi dari kasus 'Baiq Nuril', pendidik atau guru disini perlu diarahkan dan ditekankan untuk melaksanakan kegiatan pengembangan profesi yang merupakan kegiatan guru dalam rangka pengamalan ilmu dan pengetahuan, teknologi dan keterampilan untuk meningkatkan, baik bagi prosesi pembelajaran dan profesionalisme tenaga kependidikan lainnya. Jenis kegiatankegiatan yang bisa dilakukan oleh pendidik atau guru untuk pengembangan profesinya dalam hal ini dipaparkan lebih jelas sebagai berikut:

1) Mengadakan penelitian di bidang pendidikan sebagai bukti seorang akademisi.

2) Menemukan teknologi sebagai pendorong dunia pendidikan.

3) Membuat alat pelajaran atau peraga atau bimbingan.

4) Menciptakan karya tulis.

5) Mengikuti pengembangan kurikulum.

Lebih lanjut, kegiatan pengembangan profesi ini, juga merupakan bagian dari pada pelatihan bagi pendidik atau guru. Pelatihan dan pengembangan ini merupakan sesuatu yang sangat penting. Hal ini mengingat pada dasarnya kegiatan seperti itu, merupakan suatu bagian yang integral dari suatu manajemen dalam bidang ketenaga kerjaan di sekolah dan merupakan suatu cara untuk mengembangkan pengetahuan dan keterampilan guru sehingga dari sana diharapkan para guru memiliki keunggulan kompetitif, sehingga dapat melaksanakan tugas dan kewajiban dengan sebaik-baiknya (Sutriyanti, 2017: 108-109).

Kemudian jika mengkhusus untuk Kepala Sekolah, sesuai pendapat dari Sedana (2018: 183) terkait kemampuan tenaga 
pendidik sebagai agen perubahan di era 4.0, juga menyinggung sedikit saran dan peran kepala sekolah sebagai aspek di sekolah yang membangun kepribadian atas dasar mentalitas kerjasama sebagai sebuah tim yang kokoh. Mengambil kutipan dari Arifin (2007), Sedana mengatakan bahwa Kepala Sekolah perlu diwajibkan untuk:

1) Sebagai aspek yang berperan sebagai perancang (designer) kebijakan strategis terhadap aplikasi keenam konsep tersebut.

2) Sebagai aspek yang wajib berfikir integral dalam mencermati tantangan pendidikan ke depan (visioner).

3) Sebagai aspek yang mampu membangkitkan learning organization.

4) Sebagai aspek yang berkewajiban mendorong dan memotivasi setiap guru untuk mampu mengembangkan potensi profesinya secara maksimal.

5) Sebagai orang yang wajib memiliki sifat terbuka, baik pada kritik dan saran yang membangun, transparan dan bertanggung-jawab dalam pengelolaan sumber daya manusia di sekolah.

Dengan saran tersebut, diharapkan antar tenaga kependidikan dapat bekerja sama secara lebih produktif dan mampu meningkatkan kemampuan kerjanya. Sehingga, jika sudah melaksanakan ini, sikap atau kebiasaan buruk guru atau kepala sekolah yang melanggar kode etik profesinya bisa ditekan dan diarahkan untuk kegiatan yang positif. Dari sana juga, secara tidak langsung mutu etika profesi kependidikan bisa ditingkatkan dengan maksimal.

\section{SIMPULAN}

Pendidikan merupakan kunci dari pembangunan suatu bangsa kedepan, sementara tenaga pendidik dalam pendidikan itu sendiri bertugas membentuk kunci tersebut dengan cara memberikan para peserta didik bimbingan dan pengajaran. Sehingga dalam hal ini kasus yang melibatkan tenaga kependidikan seperti 'Baiq Nuril' jangan sampai terulang lagi di masa yang akan datang. Kasus 'Baiq Nuril' merupakan kasus yang terjadi akibat kurangnya kepedulian dan kepatuhan tenaga kependidikan akan etika profesi kependidikan atau kode etik profesi keguruan. Sehingga tindakan-tindakan di luar tanggung-jawab kerjanya sebagai seorang profesional, yang sifatnya melanggar nilai moral, dan tidak patut dilakukan seperti dugaan pelecehan seksual walaupun secara verbal dapat terjadi. Untuk itulah, kasus 'Baiq Nuril' yang telah terjadi ini, mesti dijadikan suatu refleksi pembelajaran bagi tenaga kependidikan. Pembelajaran ini penting, sebagai pedoman dan acuan dalam memastikan, serta menekankan guru atau tenaga pendidik lain agar memahami dan menaati secara sungguh-sungguh etika profesi kependidikan yang sudah ditetapkan, baik oleh tenaga pendidik itu sendiri, pemerintah, maupun masyarakat. Lewat kasus 'Baiq Nuril' pula, bisa menjadi refleksi untuk melahirkan pembelajaran kepada pendidik atau guru dengan cara memberikan pelatihan baru kepada para Guru yang khusus untuk membentuk karakter yang baik, disamping dengan mengarahkan guru agar melaksanakan kegiatan positif seperti melaksanakan kegiatan pengembangan profesi keguruan. Kemudian untuk Kepala Sekolah lebih ditekankan lagi kewajibannya sebagai aspek panutan warga sekolah. Dengan begitu, hal ini dirasa bisa mencegah kasus yang sama agar tidak terulang lagi, dan terutama sebagai sarana meningkatkan mutu etika profesi kependidikan.

\section{DAFTAR PUSTAKA}

Ananda, Rusydi. (2018). Profesi Pendidikan dan Tenaga Kependidikan. Medan: Lembaga Peduli Pengembangan Pendidikan Indonesia (LPPPI).

Astawa, I. N. (2018). Pola Pendidikan dalam Perspektif Pendidikan Hindu. Satya Vidya: Jurnal Studi Agama, 1 (1), 97.

CNN Indonesia, (2019). Kronologi Kasus Baiq Nuril, Bermula Dari Percakapan Telepon. [Online]. Available at: https://www.cnnindonesia.com/nasio nal/20181114133306-12- 
346485/kronologi-kasus-baiq-nurilbermula-dari-percakapan-telepon [Diakses: 27 April 2020].

Danim, Sudarwan. (2009). Manajemen dan Kepemimpinan Transformasional Kepala Sekolah. Jakarta: Rineka Cipta.

Darmadi, H. (2011). Metode Penelitian Pendidikan. Bandung: Alfabeta.

Detik.com, (2018). Kecewanya Baiq Nuril karena Polisi Setop Kasus Kepsek Cabul. [Online]. Available at: https://news.detik.com/berita/d4390073/kecewanya-baiq-nurilkarena-polisi-setop-kasus-kepsekcabul [Diakses: 27 April 2020].

Detik.com, 2019. Ujung Cerita Kasus Baiq Nuril. [Online]. Available at: https://news.detik.com/berita/d4644551/ujung-cerita-kasus-baiqnuril[Diakses: 27 April 2020].

Haris, Abd. 2010. Etika Hamka. Kontruksi Etik Berbasis Rasional-Religius. Yogyakarta: LKiS Yogyakarta.

Karuru Perdy dan Tangkeallo, Daud Kuddi. (2017). Profesi Kependidikan. Toraja: UKI Toraja Press.

Kompas.com, (2019). Perjalanan Panjang Baiq Nuril Mencari Keadilan. [Online]. Available at: https: // regional. kompas.com / read / 2019 / $07 / 09$ / $07524561 /$ perjalananpanjang-baiq-nuril-mencari-keadilan? page $=$ all [Diakses: 27 April 2020].

Marbun, Stefanus M. (2018). Psikologi Pendidikan. Ponorogo: Uwais Inspirasi Indonesia.
Nahdi, Khirjan. (2018). Pendidikan dan Modernisasi Peradaban (Paradigma Kritis Kompleksitas Variabel Pendidikan Menuju Karakter Bangsa). Yogyakarta: CAKRAWALA.

Nurmawati, N. K. Y. dan Mandra, I. W. (2018). Peranan Kepala Sekolah dalam Meningkatkan Mutu dan Kompetensi Guru Agama Hindu di Sekolah Dasar. Jurnal Penjaminan Mutu, 4 (2), 185.

Perdani, Widaya Caterine dkk. (2019). Etika Profesi Pendidikan Generasi Milenial 4.0. Malang: UB Press.

Rusman. (2011). Model-Model Pembelajaran Mengembangkan Profesionalisme Guru. Jakarta. Rajawali Press.

Sedana, I. M. (2019). Guru dalam Peningkatan Profesionalisme Agen Perubahan dan Revolusi Industri 4.0. Jurnal Penjaminan Mutu, 5 (2), 183.

Sutarsih, Cicih. (2013). Etika Profesi. Jakarta: Direktorat Jenderal Pendidikan Islam Kementerian Agama RI.

Sutriyanti, N. K. (2017). Implementing The 2013 Curriculum On Hindu Classes In The Elementary School in Denpasar.Vidya Samhita: Jurnal Penelitian Agama, 3 (1), 108-109.

Wahyuningsih, Sri. 2013. Metode Penelitian Studi Kasus (Konsep, Teori Pendekatan Psikologi Komunikasi, dan Contoh Penelitiannya). Madura: UTM Press.

Wandi, Z. N. dan Nurhafizah. (2019). Etika Profesi Guru Pendidikan Anak Usia Dini. Jurnal Pendidikan Anak Usia Dini, 2 (2), 34. 